\title{
PARTIAL ISOLATION OF A PHEROMONE ACCELERATING PUBERTY IN FEMALE MICE
}

\author{
JOHN G. VANDENBERGH, J. M. WHITSETT* AND \\ JOSEPH R. LOMBARDI* \\ North Carolina Department of Mental Health, Research Division, Raleigh, and \\ *Department of Zoology, North Carolina State University, Raleigh, \\ North Carolina 27611 , U.S.A.
}

(Received 19th November 1974)

\begin{abstract}
Summary. The sexual development of female mice is accelerated by exposure to an adult male or to male urine. The component of the urine responsible for this effect is androgen-dependent, heat labile, nondialysable, precipitatable with ammonium sulphate, and is not extractable in ether. These results indicate that the pheromone causing accelerated sexual development is associated with a protein component of male urine. Tests of the active fraction after digestion with proteolytic enzymes suggest that the pheromone may be a portion of a protein or a substance bound to a protein.
\end{abstract}

\section{INTRODUCTION}

The age at which a female mouse attains puberty is at least partly dependent upon social stimuli (Vandenbergh, 1973). Rearing female mice in the presence of other females delays the onset of puberty (Vandenbergh, Drickamer \& Colby, 1972; Drickamer, 1974). On the other hand, exposing young female mice to the presence of a male, to bedding material soiled by a male, or to male urine advances the onset of puberty (Vandenbergh, 1967, 1969; Cowley \& Wise, 1972; Colby \& Vandenbergh, 1974). The male's ability to accelerate the onset of puberty is thus apparently due to the presence of a urinary pheromone. The experiments described in this report were designed to clarify the chemical nature of this pheromone.

The chemical nature of many pheromones which have a signalling function in insects is known (Law \& Regnier, 1971) and progress has been made in the identification of some mammalian signalling pheromones which induce sexual behaviour (Curtis, Ballantine, Keverne, Bonsall \& Michael, 1971) or serve to mark territories (Müller-Schwarze, Müller-Schwarze, Singer \& Silverstein, 1974). These pheromones have proved to be fatty acids, relatively low molecular weight volatile compounds. Pheromones inducing long-term physiological changes have been termed priming pheromones (Wilson \& Bossert, 1963; Bronson, 1971). At least two reproductive phenomena in addition to sexual maturation are influenced by priming pheromones in mice. Oestrous cycles of the adult female become more regular and can be synchronous within a group 
following exposure to a male or to male urine (Whitten, 1958; Bronson \& Whitten, 1968) and pregnancy in a newly mated female can be blocked by a strange male or by exposure to urine from a strange male (Bruce, 1959; Dominic, 1966). Purification or identification of the component of male mouse urine inducing either of these priming effects has not been attained.

A major problem in attempts to isolate the urinary component containing pheromonal activity has been the absence of a relatively fast and reliable bioassay for testing fractions of urine. We have devised such a bioassay for detecting the active fraction of male urine causing accelerated sexual development of females. The bioassay procedure will be described first followed by a description of two sets of experiments. In the first set of two experiments (Exps 1 and 2), we attempted to replicate previous work (Vandenbergh, 1973) in which vaginal cornification had been used as the index of puberty. In the second set of four experiments (Exps 3,4,5 and 6) we attempted to characterize the pheromone component of male urine.

\section{MATERIALS AND METHODS}

\section{Bioassay procedure}

Closed-colony, albino mice (Mus musculus) fed Purina Mouse Chow and given free access to water were housed in $18 \times 28 \times 11 \mathrm{~cm}$ cages on San-i-cel bedding in rooms maintained at $22 \pm 2^{\circ} \mathrm{C}$ and 30 to $70 \%$ relative humidity. The light cycle in the rooms provided $14 \mathrm{hr}$ light/day with lights on from 23.00 hours. All females were born and reared in a room isolated from adult male mice. On the 2nd day after birth, all litters were standardized at six to eight young with at least one member of each sex represented. At 21 days of age, all females were weighed and those between 8.5 and $11.5 \mathrm{~g}$ were weaned, placed in individual cages and randomly assigned to treatments with the restriction that no sisters were in the same treatment group. Treatments were then randomly assigned to each experimental group. At 28 days of age (25 days of age in Exp. 5), the isolated females were exposed to substances once a day for 8 consecutive days by applying 0.03 to $0.05 \mathrm{ml}$ of a control or a test substance to the philtrum, or oronasal groove, from a $1-\mathrm{ml}$ syringe. On the 9 th day, each female was killed by cervical dislocation and weighed. Uteri were promptly removed, cleaned and weighed to the nearest $0.1 \mathrm{mg}$. All uteri were cleaned in ignorance of the treatment to which the female had been subjected.

For statistical analysis, all uterine weight data were given $\log _{10}$ transformations to correct for heterogeneity of variance among treatment groups. Such variance in uterine weight is a function of the cyclic hypertrophy of uterine tissue during the ovarian cycle. Body weight and $\log _{10}$ uterine weight data were subjected to one-way analysis of variance. Significant differences between treatment means were determined by the least significant difference method for those parameters yielding a significant $(P<0.05)$ analysis of variance.

\section{Tests of urine}

In the first experiment, the following urines were tested: (a) male mouse urine collected daily from twenty adult male stud mice, pooled and applied to 
the test females within $1 \mathrm{hr}$ after collection; (b) male mouse urine collected in a similar manner, frozen each day until $10 \mathrm{ml}$ were collected, thawed, sterilized by filtration through a Millipore Swinnex filter with $0.45 \mu \mathrm{m}$ pore size, and stored at $5^{\circ} \mathrm{C}$ during the application period of 8 days; (c) male mouse urine collected, frozen as above, and autoclaved for $30 \mathrm{~min}$ at $126^{\circ} \mathrm{C}$; (d) male rat urine collected from two adult male rats, pooled, and delivered to the test female mice within $1 \mathrm{hr}$ of collection; (e) human urine donated by a 26 -year-old sexually active male and applied to the test females within $\mathrm{I} \mathrm{hr}$ of collection. Mouse and rat urine were collected by holding the male over a beaker and gently palpating the bladder.

In Exp. 2, the three samples tested were: urine collected from twenty adult male mice as described above, urine collected from twenty-four adult male mice 35 days after castration, and water. Urine from intact and castrated males was collected 1 week before use, frozen as a pool, thawed on Day 1 of application and stored at $5^{\circ} \mathrm{C}$ during the treatment period.

\section{Tests of urine fractions}

To determine whether the pheromone was associated with the high molecular weight fraction of male urine, the effects of the non-dialysable fractions of male mouse urine and those precipitated by ammonium sulphate were tested in Exps 3 and 4, respectively. In this and subsequent experiments, urine from adult stud male mice was frozen until needed. The non-dialysable fraction was prepared by dialysing 10 to $20 \mathrm{ml}$ urine against 15 litres distilled water for $48 \mathrm{hr}$ at $5^{\circ} \mathrm{C}$ with two changes of water. The non-dialysable fraction was evaporated under $\mathrm{N}_{2}$ to near dryness and reconstituted to the original volume of urine with distilled water. The fraction of male urine precipitated by $\left(\mathrm{NH}_{4}\right)_{2} \mathrm{SO}_{4}$ was prepared by adding $\left(\mathrm{NH}_{4}\right)_{2} \mathrm{SO}_{4}$ to $8 \mathrm{ml}$ chilled male urine to give a final concentration of $80 \%$ salt. The resulting precipitate was isolated by centrifugation, reconstituted to the original volume with water, and dialysed against distilled water to remove the $\left(\mathrm{NH}_{4}\right)_{2} \mathrm{SO}_{4}$.

To prepare material for use in Exp. 5, the non-dialysable fraction of male urine was divided into three aliquots: one untreated, the second incubated with Pronase, and the third incubated with Pronase and subsequently re-dialysed. To accomplish this, $30 \mathrm{ml}$ male urine were dialysed against 15 litres distilled water for $24 \mathrm{hr}$ with one change and then against 4 litres of $0.2 \mathrm{M}-\mathrm{NH}_{4} \mathrm{HCO}_{3}$ buffer for $24 \mathrm{hr}$. After the addition of $2 \mathrm{mg}$ Calbiochem Pronase (lot no. 300114) per $\mathrm{ml}$ urine fraction ( $1 \mathrm{mg}$ Pronase $/ 2.5 \mathrm{mg}$ urinary protein), the solution was incubated for $24 \mathrm{hr}$ in a shaking water-bath at $37^{\circ} \mathrm{C}$. For re-dialysis, $12 \mathrm{ml}$ Pronase-treated material was dialysed against 4 litres buffer for $24 \mathrm{hr}$ at $5^{\circ} \mathrm{C}$.

In Exp. 6, attempts were made to separate bound lipids from the urinary protein by ether extraction and to test whether the pheromone was a lipid or other ether-soluble material bound to a protein. The non-dialysable fraction of male urine was divided into two aliquots: one untreated and the second extracted with diethyl ether after acidification to $\mathrm{pH} 4.9$ with $\mathrm{HCl}$. Both the ether and aqueous fractions were divided into two aliquots and evaporated to dryness under $\mathrm{N}_{2}$. One aliquot of each fraction was reconstituted to the original 
volume of urine with water, and tested for activity. The other aliquots were reconstituted to half the original volume, recombined and tested.

\section{RESULTS}

\section{Tests of urine}

The mean uterine weight of females exposed to fresh male mouse urine, filtered male mouse urine, or fresh male rat urine significantly exceeded the uterine weight of females exposed to water (Table 1, Exp. 1). The mean uterine weight of females exposed to autoclaved male mouse urine or male human urine did not differ significantly from that of the female controls which were exposed to water. Thus the substance is heat labile and is not the product of bacterial action on urine since cold sterilization with a filter is without effect.

Table 1. Body and uterine weights of female mice exposed to male urine compared to those of control mice exposed to water

\begin{tabular}{|c|c|c|c|}
\hline Treatment & $\begin{array}{l}\text { No. of } \\
\text { mice }\end{array}$ & $\begin{array}{c}\text { Body wt }(g) \\
(\text { Mean } \pm \text { S.E. })\end{array}$ & $\begin{array}{l}\text { Uterine wt }(m g) \\
(\text { Mean } \pm S . E .)\end{array}$ \\
\hline $\begin{array}{l}\text { Experiment } 1 \\
\text { Intact male urine } \\
\text { Filtered male urine } \\
\text { Autoclaved male urine } \\
\text { Male rat urine } \\
\text { Male human urine } \\
\text { Water } \\
\quad \text { ANOVA } †\end{array}$ & $\begin{array}{l}18 \\
18 \\
12 \\
18 \\
12 \\
18\end{array}$ & $\begin{array}{c}17 \cdot 4 \pm 0.34 \\
17 \cdot 2 \pm 0 \cdot 22 \\
17 \cdot 2 \pm 0 \cdot 39 \\
17 \cdot 2 \pm 0.30 \\
17 \cdot 3 \pm 0 \cdot 41 \\
17 \cdot 4 \pm 0 \cdot 40 \\
\text { N.S. }\end{array}$ & $\begin{array}{l}60.5 \pm 8 \cdot 74^{* *} \\
69.5 \pm 9.98^{* * *} \\
22.9 \pm 3.25 \\
52.6 \pm 6.54^{*} \\
37.5 \pm 10.57 \\
31.3 \pm 4.81 \\
P<0.0001\end{array}$ \\
\hline $\begin{array}{l}\text { Experiment } 2 \\
\text { Male mouse urine } \\
\text { Urine of castrated male mice } \\
\text { Water }\end{array}$ & $\begin{array}{l}15 \\
15 \\
15\end{array}$ & $\begin{array}{l}17.7 \pm 0.22 \\
17.2 \pm 0.31 \\
17.5 \pm 0.26\end{array}$ & $\begin{array}{l}73 \cdot 4 \pm 8 \cdot 24 * \\
31 \cdot 0 \pm 4 \cdot 53 \\
45 \cdot 8 \pm 6 \cdot 76\end{array}$ \\
\hline ANOVA $†$ & & N.S. & $P<0.001$ \\
\hline
\end{tabular}

The number of mice in Exp. 1 differed between treatments because the study was run in two experiments within 1 month and not all treatments were repeated in the second run.

* Significantly different from water at $P<0.05, * * P<0.01, * * * P<0.001$ based on comparisons of least square differences on $\log _{10}$ transformed data. $\dagger$ Within experiment analysis of variance.

In Exp. 2, the mean uterine weight of female mice exposed to urine from intact male mice was significantly greater than the uterine weight of females exposed to urine from castrated males or to water (Table 1).

\section{Tests of urine fractions}

The fractions of male urine used in Exps 3 and 4 resulted in significant uterine hypertrophy at bioassay (Table 2).

The non-dialysable fraction induced significant uterine hypertrophy both before and after incubation with Pronase in Exp. 5 (Table 2), but re-dialysis of the Pronase-treated material removed the activity. Assay (Lowry, Rosebrough, Farr \& Randall, 1951) for total proteins (excluding Pronase) revealed that the 
non-dialysable fraction contained $4.8 \mathrm{mg}$ protein $/ \mathrm{ml}$; after incubation with Pronase, this fell to $3.2 \mathrm{mg}$ and after re-dialysis, only $1.2 \mathrm{mg}$ protein $/ \mathrm{ml}$ remained. In Exp. 6, significant uterine hypertrophy resulted from treatment with the non-dialysable fraction, and with both the ether-insoluble and recombined fractions (Table 2).

Table 2. Body and uterine weights of female mice exposed to male urine, various fractions of male urine, or water

\begin{tabular}{|c|c|c|c|}
\hline Treatment & $\begin{array}{l}\text { No. of } \\
\text { mice }\end{array}$ & $\begin{array}{c}\text { Body wt }(g) \\
(\text { Mean } \pm S . E .)\end{array}$ & $\begin{array}{c}\text { Uterine wt }(m g) \\
(\text { Mean } \pm S . E .)\end{array}$ \\
\hline $\begin{array}{l}\text { Experiment } 3 \\
\text { Male urine } \\
\text { Non-dialysable fraction } \\
\text { Water } \\
\text { ANOVA } †\end{array}$ & $\begin{array}{l}16 \\
14 \\
16\end{array}$ & $\begin{array}{l}17 \cdot 8 \pm 0 \cdot 29 \\
18 \cdot 2 \pm 0 \cdot 40 \\
17 \cdot 2 \pm 0 \cdot 26 \\
\text { N.S. }\end{array}$ & $\begin{array}{c}45 \cdot 1 \pm 16 \cdot 15^{*} \\
52.9 \pm 15 \cdot 01^{*} \\
15 \cdot 2 \pm 1.49 \\
P<0.01\end{array}$ \\
\hline $\begin{array}{l}\text { Experiment } 4 \\
\mathrm{Non}^{2} \text {-dialysable fraction } \\
\left(\mathrm{NH}_{4}\right)_{2} \mathrm{SO}_{4} \text {-precipitated } \\
\text { fraction } \\
\text { Water } \\
\quad \text { ANOVA } \dagger\end{array}$ & $\begin{array}{l}14 \\
15 \\
13\end{array}$ & $\begin{array}{l}18 \cdot 2 \pm 0 \cdot 23 \\
18 \cdot 2 \pm 0 \cdot 37 \\
17 \cdot 3 \pm 0 \cdot 25 \\
\text { N.S. }\end{array}$ & $\begin{array}{c}57 \cdot 6 \pm 10 \cdot 24^{* * *} \\
52 \cdot 2 \pm 10 \cdot 83^{* * *} \\
15 \cdot 2 \pm 1 \cdot 21 \\
P<0.0001\end{array}$ \\
\hline $\begin{array}{l}\text { Experiment } 5 \\
\text { Non-dialysable fraction } \\
\text { Non-dialysable fraction }+ \\
\text { Pronase } \\
\text { Non-dialysable fraction }+ \\
\text { Pronase + re-dialysed fraction } \\
\text { Buffer } \\
\text { ANOVA } \uparrow\end{array}$ & $\begin{array}{l}15 \\
15 \\
15 \\
15\end{array}$ & $\begin{array}{l}17 \cdot 4 \pm 0 \cdot 25 \\
17 \cdot 4 \pm 0 \cdot 23 \\
17 \cdot 3 \pm 0 \cdot 23 \\
17 \cdot 1 \pm 0 \cdot 36 \\
\text { N.S. }\end{array}$ & $\begin{array}{c}43.4 \pm 12 \cdot 33^{* *} \\
36.4 \pm 6.34^{* *} \\
18.4 \pm 2.13 \\
17.9 \pm 1.77 \\
P<0.01\end{array}$ \\
\hline $\begin{array}{l}\text { Experiment } 6 \\
\text { Non-dialysable fraction } \\
\text { Ether-soluble fraction } \\
\text { Ether-insoluble fraction } \\
\text { Recombined fraction } \\
\text { Water } \\
\text { ANOVA } \dagger\end{array}$ & $\begin{array}{l}14 \\
14 \\
14 \\
14 \\
14\end{array}$ & $\begin{array}{l}18 \cdot 9 \pm 0.23 \\
17.5 \pm 0.33 \\
18.2 \pm 0.29 \\
18.2 \pm 0.39 \\
17.6 \pm 0.23 \\
P<0.02\end{array}$ & $\begin{array}{l}67.4 \pm 11 \cdot 58^{* * *} \\
25.4 \pm 67.9 \\
43.8 \pm 13.32^{*} \\
51.2 \pm 15.27^{*} \\
17.6 \pm 1.31 \\
P<0.001\end{array}$ \\
\hline
\end{tabular}

* Significantly different from water or buffer control at $P<0.05, * * P<0.01$, $* * * P<0.001$ based on least significant difference comparisons on $\log _{10}$ transformed data.

$\uparrow$ Within-experiment analysis of variance.

In addition to the results of specific experiments described separately above, a number of findings emerged when the experiments were examined as a group. There were no significant differences in mean body weight at weaning in any of the experiments reported above but in one experiment (Exp. 6), there was a significant difference between treatments in mean body weight at autopsy. In four of the six experiments, there was a more rapid weight gain among females exposed to active fractions than among those exposed to water or to inactive fractions.

The mean uterine weight of female mice exposed to water differed considerably from experiment to experiment. The source of this variation in female uterine growth was apparently a seasonal factor because bioassays of male 
mouse urine versus water at different times of the year revealed that uterine growth was greater in spring and summer than in autumn and winter (Text-fig. 1). The uterine weight of females exposed to water reached a peak in June and was at its lowest in November. The effect of male urine on uterine hypertrophy was apparent at all seasons of the year but the rate of uterine growth apparently shifted with season.

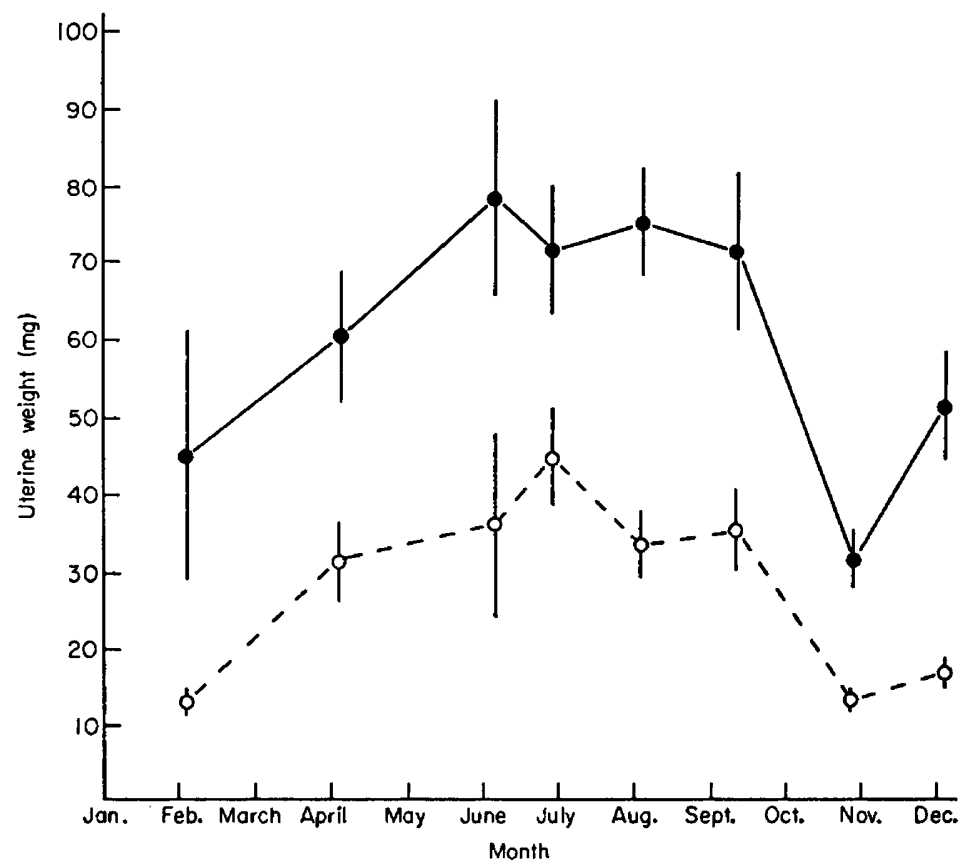

TEXT-FIG. 1. Seasonal changes in the uterine weight response of female mice to male urine $(\bullet)$ and water $(0)$. Each point represents the mean ( \pm S.E. - vertical lines) of twelve to fifteen uteri.

\section{DISCUSSION}

The results of bioassays of whole urine from various donors shows that the pheromone accelerating female sexual development is contained in the urine of male mice and rats, thus confirming our previous findings (Colby \& Vandenbergh, 1974). We also confirmed the finding of Colby \& Vandenbergh (1974) that the presence of the pheromone is androgen-dependent.

The finding that the pheromone was contained in the non-dialysable fraction of male urine in Exp. 3 suggests that the pheromone is associated with the high molecular weight fraction of male urine since dialysis removed material of low molecular weight. The ability of ammonium sulphate to precipitate the pheromone further indicates that it is associated with the protein fraction of male urine.

An association between the pheromone and the protein component of urine is surprising because urinary proteins are at extremely low concentrations in most mammals. It may be an interesting coincidence that the urine of mice contains 
relatively high levels of protein (Parfentjev, 1932; Wicks, 1941) averaging about 100 times the human urinary protein concentration. Furthermore, the protein content of male urine is androgen-dependent because its concentration increases at puberty (Thung, 1955), declines after castration (Thung, 1962), and is found at higher concentration in males than in females (Wicks, 1941). Male rats and a few other rodents also secrete considerable quantities of urinary protein (Finlayson \& Baumann, 1958; Finlayson \& Morris, 1965; Finlayson, Potter, Shinnick \& Smithies, 1974). The origin of the androgen-dependent urinary protein is hepatic and it is excreted by the kidney (Rümke \& Thung, 1964; Finlayson, Asofsky, Potter \& Runner, 1965).

Although there is a correlation between the presence of an androgendependent protein and the androgen-dependent pheromone, experimental evidence is not yet available to confirm that they are the same substance. As yet no function has been ascribed to the high levels of urinary proteins found in male rodents and they have been thought of as a metabolic curiosity (Hoffman, 1970). It is possible that these proteins act as pheromones or as carriers of pheromones which influence females.

In Exp. 5, the enzyme mixture, Pronase, apparently digested much of the protein in the urine and yet the Pronase-treated material retained activity in the bioassay. This activity disappeared, however, following re-dialysis of the Pronase-treated material indicating that the Pronase may have broken the protein molecule into fragments which were then of sufficiently low molecular weight to pass through the dialysis tubing. If this interpretation is correct, the pheromone may be a portion of a large protein molecule found in male urine.

An alternative interpretation of these results is that the pheromone is a substance bound to a carrier protein which is stripped off by Pronase and thus becomes susceptible to dialysis. This interpretation as it applies to ethersoluble substances was examined in Exp. 6. The insolubility of the pheromone in ether indicates that it is probably not a steroid or other lipid hydrophobically bound to a protein. Substances co-valently bound or substances insoluble in ether remain as candidates.

The association of the pheromone with the protein component of male urine plus its resistance to evaporation indicates that the pheromone is not volatile when excreted by the male. Vandenbergh (1969) had previously concluded that the pheromone accelerating puberty was an airborne stimulus because male mice influenced the sexual maturation of young females even when separated from them by a wire-mesh barrier. It was possible that urine or urine-contaminated bedding could have been transferred across the mesh to produce this effect, or that other cues from the male are also capable of accelerating puberty in females.

The pheromone is probably transmitted by direct contact of the female with male urine. It may be stimulating the olfactory or gustatory senses or may enter the blood stream through direct absorption or through ingestion. Additional research is needed to determine how the pheromone is influencing the hypothalamic-hypophysial-gonadal axis. Weir (1973) has suggested that a substance from the chin gland of the male cuis (Galea musteloides) may be transferred to the female by ingestion to facilitate the induction of oestrus. 
The possibility that the pheromone inducing accelerated sexual development is the same substance as that which induces synchronous oestrus in adult female mice has been suggested by Bronson (1971). The answer is apparently negative for two reasons. First, the pheromone accelerating puberty is not an airborne pheromone whereas the pheromone synchronizing oestrus apparently is (Whitten, Bronsen \& Greenstein, 1968). Secondly, the accelerating pheromone is not secreted by the preputial gland (Colby \& Vandenbergh, 1974) whereas recent evidence presented by Chipman \& Albrecht (1974) indicates that the synchronizing pheromone is at least partly a result of secretions from the preputial gland. The partial purification of the pheromone accelerating puberty will permit a more definitive test of whether one substance induces both effects.

The underlying cause for seasonal variation in uterine weight observed in these experiments is unknown because all animals were maintained under conditions of controlled photoperiod, temperature, and humidity throughout the year and the bioassay procedure was not varied among experiments. Because of this seasonal variation, valid comparisons can only be made with controls exposed to water tested simultaneously with experimental groups. A similar variation in the onset of puberty has been noted in rats maintained in a light- and temperature-controlled environment (Ramaley \& Bunn, 1972).

\section{AGKNOWLEDGMENTS}

We thank Dr John G. MacConnell, Dr Donald E. Smith, Dr Walter J. Dobrogosz and Dr John S. Finlayson for helpful advice on chemical techniques. This research was supported in part by NIMH grant MH-16870.

\section{REFERENCES}

BRonson, F. H. (1971) Rodent pheromones. Biol. Reprod. 4, 344-358.

Bronson, F. H. \& WhITTEN, W. K. (1968) Oestrus-accelerating phermone of mice: assay, androgendependency and presence in bladder urine. $\mathcal{J}$. Reprod. Fert. 15, 131-134.

Bruce, H. M. (1959) An exteroceptive block to pregnancy in the mouse. Nature, Lond. 184, 105.

GHIPMAN, R. K. \& AlBRECht, E. D. (1974) The relationship of the male preputial gland to the acceleration of oestrus in the laboratory mouse. 7. Reprod. Fert. 38, 91-96.

Golby, D. R. \& VANDENBeRGH, J. G. (1974) Regulatory effects of urinary pheromones on puberty in the mouse. Biol. Reprod. 11, 268-279.

GowLEY, J. J. \& WISE, D. R. (1972) Some effects of mouse urine on neonatal growth and reproduction. Anim. Behav. 20, 499-506.

Gurtis, R. F., Ballantine, J. A., Keverne, E. B., Bonsall, R. W. \& Michael, R. P. (1971) Identification of primate sexual pheromones and the properties of synthetic attractants. Nature, Lond. 232, 396-398.

Dominıc, C. J. (1966) Block to pseudopregnancy in mice caused by exposure to male urine. Experientia, 22, 534-535.

Drickamer, L. G. (1974) Sexual maturation of female mice: social inhibition. Devl Psychobiol. 7, 257265.

Findayson, J. S. \& Baumann, G. A. (1958) Protein-bound sterols in rodent urine. Am. F. Physiol. 190, 297-302.

Finlayson, J. S. \& Morris, H. P. (1965) Molecular size of rat urinary protein. Proc. Soc. exp. Biol. Med. $119,663-666$.

Finlayson, J. S., Asofsky, R., Potter, M. \& Runner, G. G. (1965) Major urinary protein complex of normal mice: origin. Science, $\mathcal{N} . Y .149,981-982$.

Finlayson, J. S., Potter, M., Shinnick, G. S. \& Smithies, O. (1974) Components of the major urinary protein complex of inbred mice: determination of $\mathrm{NH}_{2}$-terminal sequences and comparison with homologous components from wild mice. Biochem. Genet. 11, 325-335. 
Horfman, H. A. (1970) Starch-gel electrophoresis of murine major urinary protein. Proc. Soc. exp. Biol. Med. 135, 81-83.

Law, J. H. \& Regnier, F. E. (1971) Pheromones. A. Rev. Biochem. 40, 533-548.

Lowry, O. H., Rosebrough, N. J., Farr, A. L. \& Randal,, R. J. (1951) Protein measurement with the Folin phenol reagent. F. biol. Chem. 193, 265-275.

Müller-Schwarze, D., Müller-Schwarze, G., Singer, A. G. \& Silverstein, R. M. (1974) Mammalian pheromone: identification of active component in the subauricular scent of the male pronghorn. Science, N.X. 183, 860-862.

Parfentjev, I. A. (1932) Galcium and nitrogen content in urine of normal and cancer mice. Proc. Soc. exp. Biol. Med. 29, 1285-1286.

Ramaley, J. A. \& BunN, E. L. (1972) Seasonal variations in the onset of puberty in rats. Endocrinology, 91, 611-613.

Rümke, P. \& Thung, P. J. (1964) Immunological studies on the sex-dependent prealbumin in mouse urine and its occurrence in the serum. Acta endocr., Copenh. 47, 156-164.

Thung, P. J. (1955) Age changes in the mouse kidney. In Old Age in the Modern World, pp. 150-154. Livingstone, Edinburgh.

Thung, P. J. (1962) Physiological proteinuria in mice. Acta physiol. pharmac. néerl. 10, 248-261.

VANDENBERGi, J. G. (1967) Effect of the presence of a male on the sexual maturation of female mice. Endocrinology, 81, 345-349.

VANDENBergh, J. G. (1969) Male odor accelerates female sexual maturation in mice. Endocrinology, 84, $658-660$.

Vandenbergh, J. G. (1973) Acceleration and inhibition of puberty in female mice by pheromones. 7. Reprod. Fert., Suppl. 19, 411-419.

VANDenberGh, J. G., Drickamer, L. C. \& Golby, D. R. (1972) Social and dietary factors in the sexual maturation of female mice. F. Reprod. Fert. 28, 397-400.

WeIR, B. J. (1973) The rôle of the male in the evocation of oestrus in the cuis, Galea musteloides (Rodentia: Hystricomorpha). F. Reprod. Fert., Suppl. 19, 421-432.

Wicks, L. F. (1941) Sex and proteinuria in mice. Proc. Soc. exp. Biol. Med. 48, 395-400.

WiLson, E. O. \& BosserT, W. A. (1963) Ghemical communication among animals. Recent Prog. Horm. Res. 19, 673-716.

WhrTtEN, W. K. (1958) Modification of the oestrous cycle of the mouse by external stimuli associated with the male. F. Endocr. 13, 399-404.

Whitren, W. K., Bronson, F. H. \& Greenstein, J. A. (1968) Estrus-inducing pheromone of male mice: transport by movement of air. Science, N.Y. 161, 584-585. 